\title{
PENGEMBANGAN SINKRONISASI MULTIPLE BOOKING AND PAYMENT SITE DALAM SATU DASHBOARD
}

\author{
I Gede Totok Suryawan', Ary Wira Andika² \\ Program Studi Teknik Informatika, STMIK STIKOM Indonesia ${ }^{1)}$ \\ Program Studi Manajemen, Universitas Mahasaraswati ${ }^{2)}$ \\ Denpasar, Bali \\ totok.suryawan@stiki-indonesia.ac.id ${ }^{1)}$ arywira@unmas.ac.id 2)
}

\begin{abstract}
This paper discusses the development of tour and activities product management, booking engine and payment facilities that are integrated with the payment gateway. This is done to solve problems experienced by tour and activities business owners related to product management facilities, booking engines, and payments on their website. Most of the tour websites and activities are not equipped with product management, booking engines, and payments, so they require special skills in managing the website, also allowing loss due to cancellation of transactions carried out by tourists. In this study an engine for product management, booking engine, and payment has been developed that is integrated with the payment gateway. The method used in developing this system uses Scrum model ranging from determining product backlogs, sprints, scrum meetings, to demo to clients. The results of the study show that the system developed can facilitate tour and activity business owners in managing tour products and activities, and facilitate tourists in ordering and paying for their products.
\end{abstract}

Keywords: Booking Engine, Payment Gateway, Tour and Activities, Scrum Model.

\begin{abstract}
ABSTRAK
Paper ini membahas tentang pengembangan manajemen produk tour dan activities, booking engine dan fasilitas pembayaran yang terintegrasi dengan payment gateway. Ini dilakukan untuk menyelesaikan masalah yang dialami oleh pemilik usaha tour dan activities terkait dengan fasilitas manajemen produk, booking engine, dan pembayaran di website mereka. Sebagian besar website tour dan activities sekarang tidak dilengkapi dengan manajemen produk, booking engine, dan pembayaran, sehingga memerlukan keterampilan khusus dalam mengelola websitenya, juga memugkinkan timbul kerugian akibat pembatalan transaksi yang dilakukan oleh wisatawan. Pada penelitian ini telah dikembangkan sebuah engine untuk manajemen produk, booking engine, dan pembayaran yang terintegrasi dengan payment gateway. Metode yang digunakan dalam pengembangan sistem ini menggunakan Scrum model mulai dari menentukan product backlog, sprint, scrum meeting, hingga demo ke client. Hasil penelitian menunjukkan bahwa sistem yang dikembangkan dapat mempermudah pemilik usaha tour dan activities dalam mengelola produk tour dan activitiesnya, serta memudahkan wisatawan dalam melakukan pemesanan dan pembayaran produknya.
\end{abstract}

Kata Kunci : Booking Engine, Payment Gateway, Tour dan Activities, Scrum Mod 


\section{PENDAHULUAN}

Website menjadi salah satu media bagi perusahaan untuk memperkenalkan produk dan profile perusahaan kepada calon pelangganya. Dengan website juga mampu memperluas segmentasi pasar, meningkatkan kualitas layanan hingga meningkatkan kreadibilitas perusahaan. Beberapa perusahaan juga mampu mendatangkan omset dari website yang mereka punya, seperti misalnya perusahaan penyedia jasa tour dan activities bisa mendatangkan wisatawan dengan memperkenalkan produk dan layanan lewat website.

Dari survei awal yang dilakukan, sebagian besar website penyedia jasa tour dan activities tidak dilengkapi dengan manajemen produk, booking engine, serta fasilitas pembayaran. Sehingga untuk memperbaharui produk mereka di website, mereka harus memiliki keterampilan khusus terkait dengan pengelolaan website, tidak semua penyedia jasa tour dan activities bisa melakukan ini. Terlebih bagi pengusaha yang memiliki website lebih dari satu mereka harus mengelola produk mereka di masing-masing website yang dimiliki. Pemesan paket tour dilakukan melalui email, watshapp, mesangger, atau telpon. Dan pembayaran dilakukan setelah wisatwan menggunakan jasa tour dan aktivitiesnya. Hal ini memungkinkan terjadinya pembatalan pesanan sepihak oleh wisatawan karena tidak ada pembayaran di awal.

Berdasarkan permasalahan tersebut, pada penelitian ini telah dikembangkan sistem pengelolaan, pemesanan dan pembayaran produk tour dan activities yang terintegrasi dengan payment gateway. Pengelolan produk dilakukan dalam satu dashboard client pada sistem ini yang selanjutnya produk tersebut bisa ditampilkan di beberapa website client (penyedia jasa tour dan activities). Pemesanan dilakukan di website client dan dilanjutkan dengan pembayaran menggunakan virtual account yang disediakan oleh payment gateway. Setiap transaksi pemesanan dan pembayaran dari wisatawan akan tercatat di dashboard client.

\section{TINJAUAN PUSTAKA}

\section{Online Booking System (OBS)}

Sistem pemesanan online atau OBS merupakan suatu sistem pemesanan berbasis web yang menggunakan media internet sehingga memungkinkan seseorang untuk memesan barang ataupun jasa tanpa bertatap muka secara langsung. Salah satu penerapan OBS adalah sistem pemesanan tiket bus online yang memungkinkan seseorang melakukan pembelian tiket bus melalui halaman website, dan sistem mampu membantu perusahaan dapat memberikan layanan reservasi dan informasi kepada pelanggan mereka tanpa batasan jam kantor atau tenaga kerja [1].

OBS juga sering digunakan dalam sistem reservasi kamar hotel, dengan sistem informasi reservasi online memungkinkan untuk mengetahui ketersedian kamar hotel oleh pengguna di luar lokasi hotel. Dan dengan teknologi web service sistem informasi reservasi hotel juga bisa diintegrasikan dengan sistem yang lain yang dgunakan pada hotel tersebut [2]. Dengan penggunaan OBS terbuti bisa memberikan kemudahan, manfaat, dan pengguna mendapatkan kepuasan saat menggunakan OBS [3].

\section{Application Programing Interface (API)}

API merupakan sekumpulan sintak yang berisi perintah atau fungsi yang dapat digunakan untuk berinteraksi dengan sistem operasi tertentu atau program pengendalian lainnnya misalnya sistem manajemen database (DBMS). Sebuah API dapat dimplementasikan dengan menulis sintaks dalam program yang menyediakan sarana untuk meminta layanan program tersebut.

$$
\text { Salah satu contoh google }
$$

menyediakan API untuk peta atau yang sering disebut google map API, dengan google map API ini memungkinkan pengembang website untuk mengintegrasikan google map ke dalam websitenya sehingga pengunjung websitenya bisa melihat peta di website yang dikembangkan. Google map API juga bisa dintegrasikan dengan aplikasi pencarian taxi. Dengan google map API memungkinkan menampilkan marker posisi taksi terdekat pada peta sehingga pengguna dapat melihat dan memilih taksi sesuai dengan jarang yang mereka inginkan [4].

\section{Payment Gateway}

Payment gateway merupakan sistem transaksi online yang mengotorisasi proses pembayaran, baik yang menggunakan kartu kredit transfer bank, atau pembayaran langsung lainnya, seperti direct debit dan $e$ - 
wallet. Dengan payment gateway otorisasi dan settlement (penyelesaian transaksi) bisa dilakukan pada saat transaksi online [5].

Dengan payment gateway juga memungkinkan toko online tidak perlu lagi menyediakan banyak rekening dari berbagai bank karena payment gateway bisa menerima dana transfer dari berbagai rekening bank dan menyalurkannya ke satu rekening milik toko online. Transaksi masal bisa dilakukan dengan cepat dan aman karena payment gateway dapat memproses ratusan hingga ribuan transaksi dalam waktu yang sangat singkat dengan rata-rata 0.052 sekon [6]. Salah satu penggunaan payment gateway yaitu pada aplikasi penjualan pulsa, dengan payment gateway pembayaran pembelian pulsa bisa dilakukan secara online [7].

\section{METODE PENELITIAN}

\section{Tahapan Penelitian}

Secara umum penelitian ini menghasilkan sebuah sistem untuk mengelola produk tour dan activities dalam satu dashboard untuk ditampilkan di beberapa website, serta mengelola pemesanan dan pembayaran dari wisatawan. Detail tahapan penelitian bisa dilihat pada Gambar 1 berikut ini.

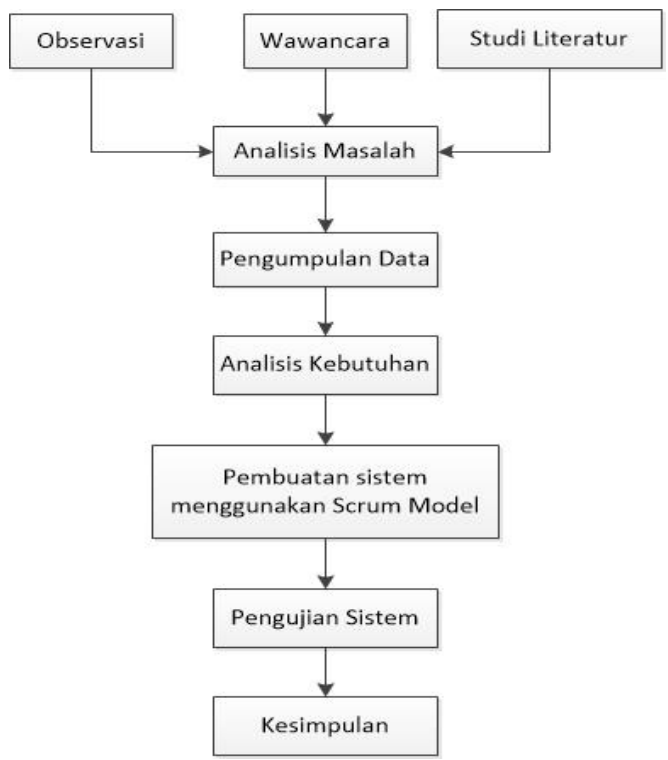

Gambar 1. Tahapan Penelitian

Seperti yang terlihat pada 1 bahwa penelitian dimulai dengan melakukan observasi dan wawancara ke penyedia jasa tour \& activities serta melakukan study literatur tentang beberapa penelitian yang sudah dilakukan terkait pengembangan online booking system dan pengembangan sistem menggunakan Scrum model. Dari hasil observasi dan wawancara kemudian dilakukan analisis permasalahan yang dialami penyedia jasa tour \& activities saat ini, dan mengumpulkan data-data terkait dengan sistem reservasi dan pembayaran paket tour \& activities. Dari permasalahan serta data-data pendukung yang ada bisa melakukan analisis kebutuhan sistem yang akan dikembangkan.

Dari hasil analisis kebutuhan tersebut dibuat gambaran umum sistem dan selanjutnya akan dikembangkan menggunakan metode Scrum model yang akan dibahas pada poin selanjutnya. Hasil pengembangan sistem tersebut dilakukan pengujian fungsional untuk memastikan setiap fitur bisa berjalan dengan baik sesuai dengan skenario pengujian yang disediakan.

\section{Metode Penelitian}

Metode penelitian yang digunakan dalam pengembangan sinkronisasi multiple booking dan payment site dalam satu dashboard ini menggunakan Scrum model. Mulai dari menentukan produck backlog, merencanakan sprint, melakukan dialy stand up meeting, melakukan sprint review, dan melakukan sprint retrospective [8], [9], [10]. Ada 6 backlog item yang dikembangkan dalam penelitian ini diantaranya: Pengelolaan data client, Integrasi multiple website client dengan sistem, Pengelolaan data pick up, Pengelolaan data Vehicle, Pengelolaan data tour, Pengelolaan data booking.

\section{Teknik Pengumpulan Data}

Adapun beberapa teknik pengumpulan data yang digunakan dalam penelitian ini diantaranya sebagai berikut :

1. Observasi

Penulis melakukan pengamatan secara langsung terhadap beberapa website penyedia jasa tour dan activities. Hasil pengamatan menunjukkan bahwa sebagian besar website tour dan actvities di Bali belum memiliki fasilitas pemesanan dan pembayaran online.

2. Wawancara

Penulis melakukan wawancara dengan penyedia jasa tour dan activiites dimana mereka menyampaikan sangat memerlukan fasilitas pengelolaan produk, pemesanan, dan pembayaran pada website meraka. Hal ini dibutuhkan selain untuk memudahkan pengelolaan produk dan 
pemesanan mereka juga berharap dengan fasilitas ini bisa menigkatkan direct booking atau pemesanan langsung oleh wisatawan melalui websitenya.

3. Studi Pustaka

Studi pustakan penulis lakukan dengan mempelajari penelitian-penelitian yang sudah pernah dilakukan terkait pengembangan online booking system, serta pengembangan sistem dengan konsep agile khususnya Scrum model.

\section{Gambaran Umum Sistem}

Dari hasil analisis yang telah dilakukan sebelumnya berikut adalah gambaran umum sistem yang telah dikembangkan.

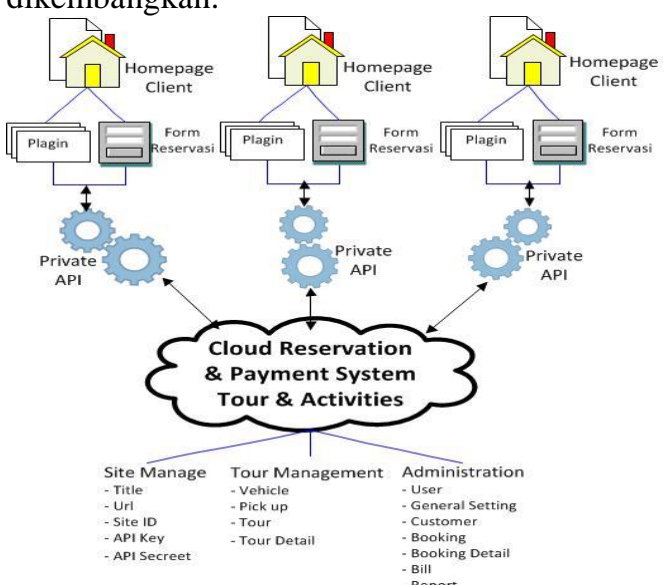

Gambar 2. Gambaran Umum Sistem

\section{HASIL DAN PEMBAHASAN}

\section{Pengelolaan data Client}

Sebelum client menggunakan sistem Cloud Reservation dan Payment System untuk Tour \& Activities ini, client harus melakukan registrasi dengan mengisi form registrasi seperti yang ditunjukan oleh Gambar 3 berikut ini.

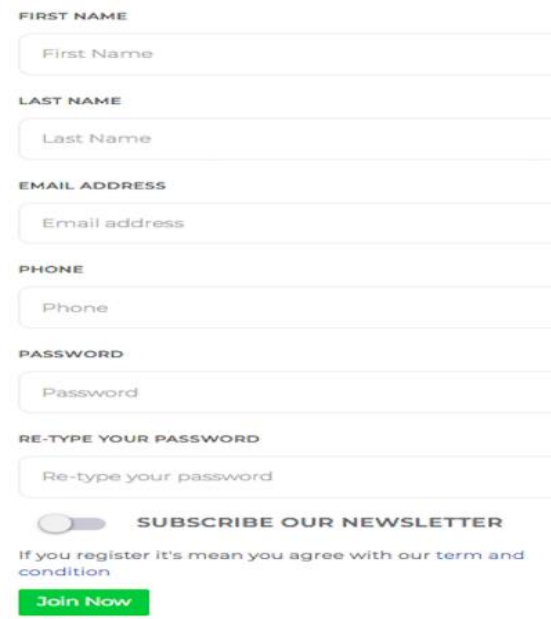

Gambar 3. Form Registrasi Client

Setelah client melakukan registrasi, client bisa melakukan login untuk menggunakan sistem cloud ini menggunakan form login seperti yang ditunjukan oleh Gambar 4 berikut ini.

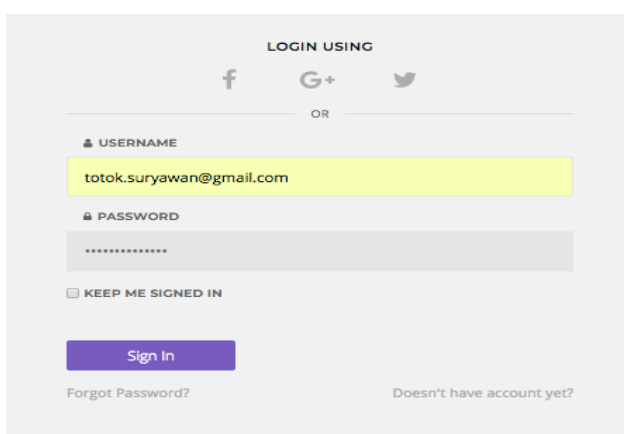

Gambar 4. Form Login Client

Seperti yang terlihat pada Gambar 4 pada form login tersebut juga disediakan fasilitas Forget Password untuk digunakan merubah password oleh client yang lupa dengan password loginya. Tahapan reset password dimulai dari memasukan email client yang terdaftar di sistem seperti yang ditunjukan pada Gambar 5 berikut ini.

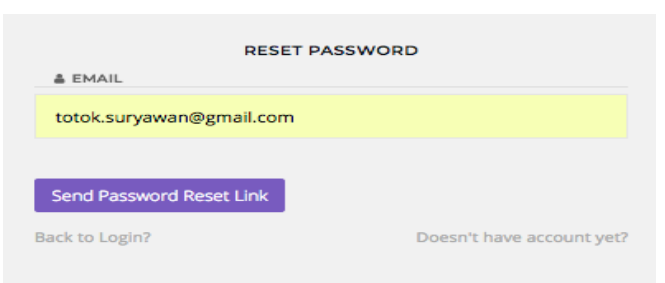

\section{Gambar 5. Form Email untuk Reset Password}

Seperti yang terlihat pada Gambar 5 di form tersebut client bisa input email yang terdaftar di sistem dan selanjutnya bisa menekan tombol reset link untuk dikirimkan URL reset password ke email yang tersebut 
seperti yang ditunjukan oleh Gambar 6 Berikut ini.

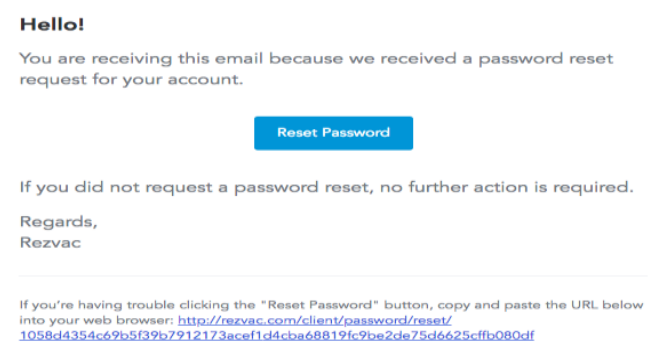

Gambar 6 URL Reset Password di Email Client

Setelah menekan tombol Reset Password di email client, makan ada didirek ke form untuk merubah password di sistem Cloud Reservation dan Payment System untuk Tour \& Activities seperti yang ditunjukan oleh Gambar 7 berikut ini.

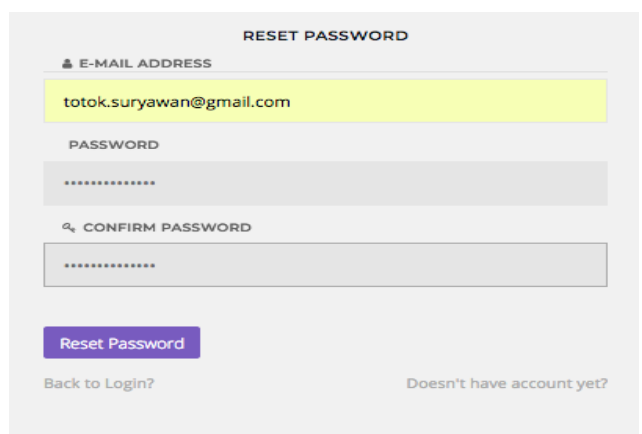

Gambar 7 Form Reset Password

\section{Manajemen Site}

Tahapan pertama yang dilakukan untuk mengintegrasikan sistem Cloud Reservation dan Payment System untuk Tour $\&$ Activities ini adalah melakukan konfigurasi URL dan API di menu site manage seperti yang ditunjukan oleh Gambar 8 berikut ini.

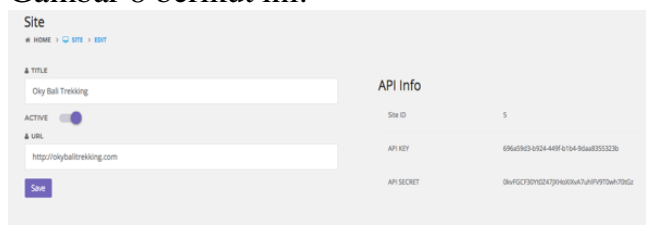

Gambar 8 Site Manage di Dashboard Client

Site ID, API Key dan API Secreet yang tercatat di dashboard client harus sama dengan yang tercatat di plagin yang terinstall di dashboard website client seperti yang ditunjukan pada Gambar 9 berikut ini.

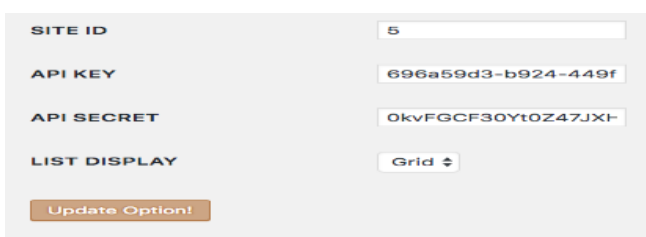

Gambar 9 Site Manage pada Plagin di Dasboard Website Client

\section{Pengelolaan Data Pickup}

Data pickup digunakan untuk memberikan pilihan tempat penjemputan wisatawan sebelum melakukan tour, sebagian data pickup berbayar dan sebagian ada yang gratis. Berikut Gambar 10 merupakan tampilan pengelolaan data pickup.

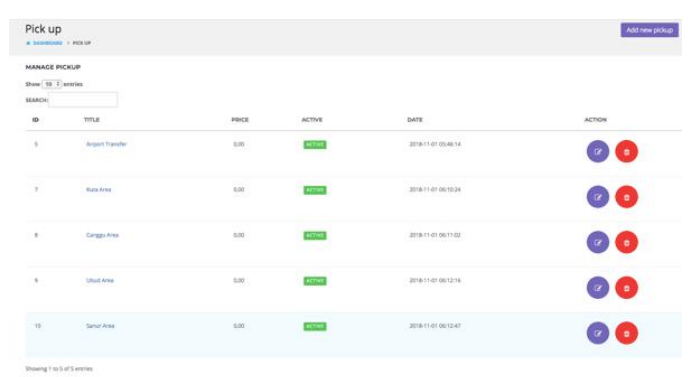

Gambar 10 Pengelolaan Data Pickup Seperti yang terlihat pada Gambar 10 untuk melihat detail data pickup bisa menekan nama pickup yang sudah dilengkapi url yang mengarah ke detail data pickup. Untuk merubah data pickup bisa menggunakan simbol edit di kolom action, begitu juga untuk menghapus data pickup bisa menggunakan simbol delete yang ada pada kolom action. Sedangkan untuk menambah data pickup yang baru bisa menggunakan tombol add new pickup yang terletak di pojok kanan atas halaman pickup.

\section{Pengelolaan Data Kendaraan}

Data kendaraan ini digunakan oleh client yang menyediakan berbagai jenis kendaraan untuk paket tournya. Berikut Gambar 11 menunjukan halaman pengelolaan kendaraan.

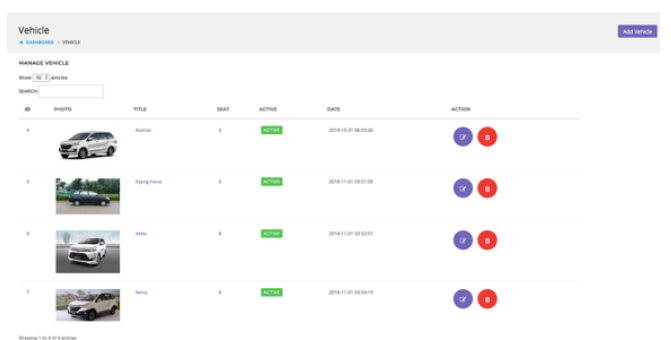

Gambar 11 Pengelolaan Data Kendaraan

Seperti yang terlihat pada Gambar 11 bahwa detail data kendaraan bisa dilihat dengan menekan nama kendaraan yang sudah dilengkapai url yang mengarah ke detail data kendaraan. Untuk merubah atau menghapus data kendaraan bisa 
menggunakan tombol simbol edit atau hapus yang terletak di kolom action. Sedangkan untuk menambahkan kendaraan baru bisa menggunakan tombol add vehicle.

\section{Pengelolaan Data Tour \& Actitivies}

Untuk menampilkan produk tour \& activities di website client, pemilik jasa tour \& activities yang sudah berhasil login ke dashboard client bisa menambahkan produk tournya menggunakan form tour seperti pada Gambar 12 berikut ini.

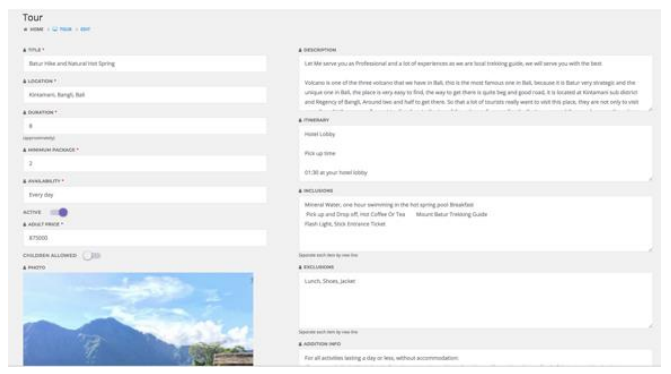

Gambar 12 Form untuk Menambahkan Tour di Dashboard Client

Setelah menambahkan beberapa tour di dashboard client bisa melakukan manajemen untuk setiap tour yang sudah diinput sebelumnya seperti yang terlihat pada Gambar 13 berikut ini.

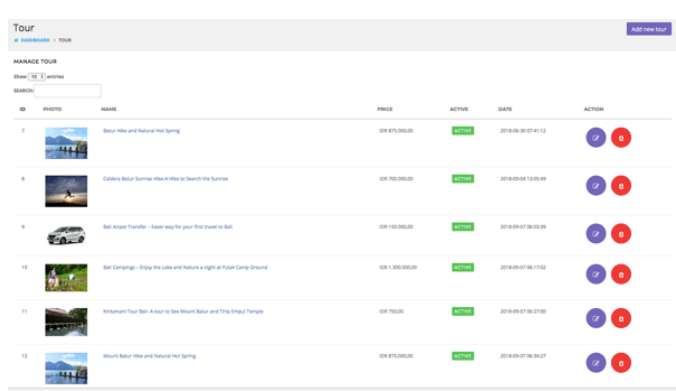

Gambar 13 Manajemen Tour di Dashboard Client

Setiap produk tour \& activities yang ditambahkan di dashboard client akan muncul sebagai tour list di website client seperti yang terlihat pada Gambar 14 berikut ini.

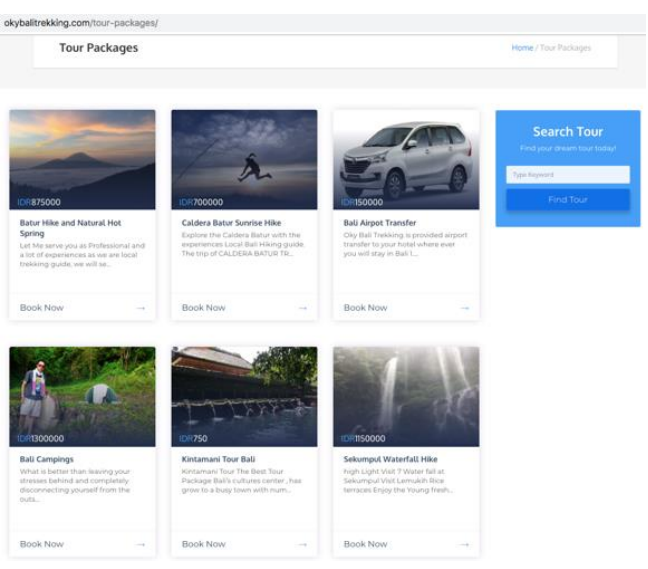

Gambar 14 Tour List di Website Clinet

Pengelolaan Data Booking dan Payment

Sebelum melakukan pemesanan customer bisa melihat detail produk tour yang ditampilakan di website client seperti yang ditunjukan pada Gambar 15 berikut ini.

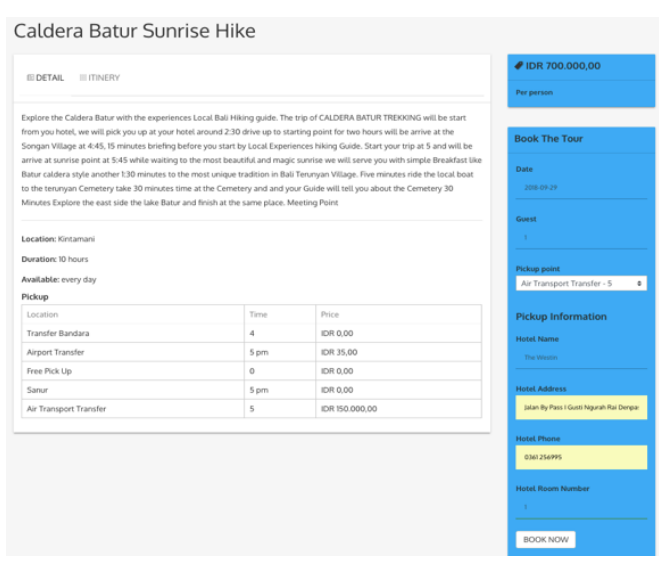

Gambar 15 Detail Tour di Website Client

Seperti yang terlihat pada Gambar 15 setelah melihat detail tour customer bisa langsung melakukan pemesanan paket tour dengan mengisi form yang di tampilkan di sidebar bagian kanan pada halaman detail tour di website client. Selanjutnya setelah mengisi form booking customer diminta mengisi detail reservasi yang dilakukan seperti yang ditunjukan oleh Gambar16 berikut ini. 


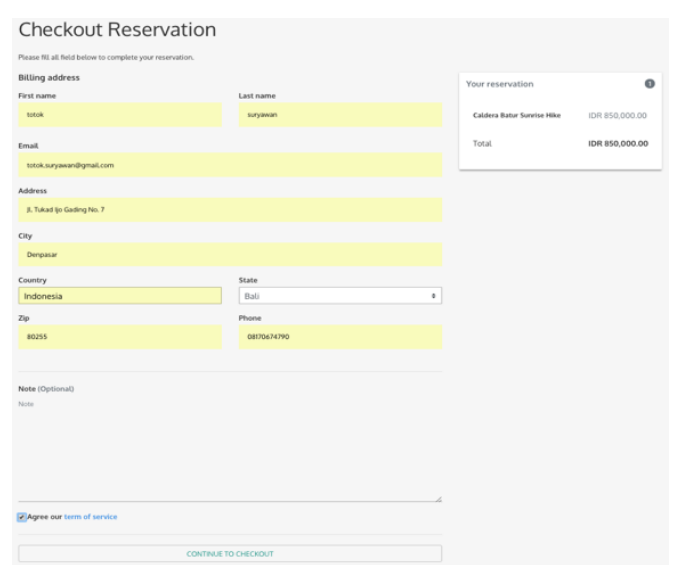

\section{Gambar 16 Form Detail Reservasi} Customer

Selanjutnya setelah mengisi form detail reservasi customer akan disuguhkan halaman detail pesanan dan cara melakukan pembayaran seperti yang ditunjukan oleh Gambar 17 berikut ini.

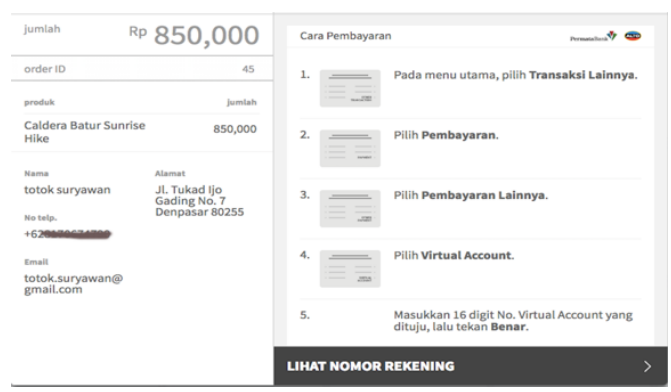

Gambar 17 Detail Pesanan dan Cara Melakukan Pembayaran
Selain di halaman website client, customer juga akan menerima tagihan di email seperti yang ditunjukan oleh Gambar 18 berikut ini.

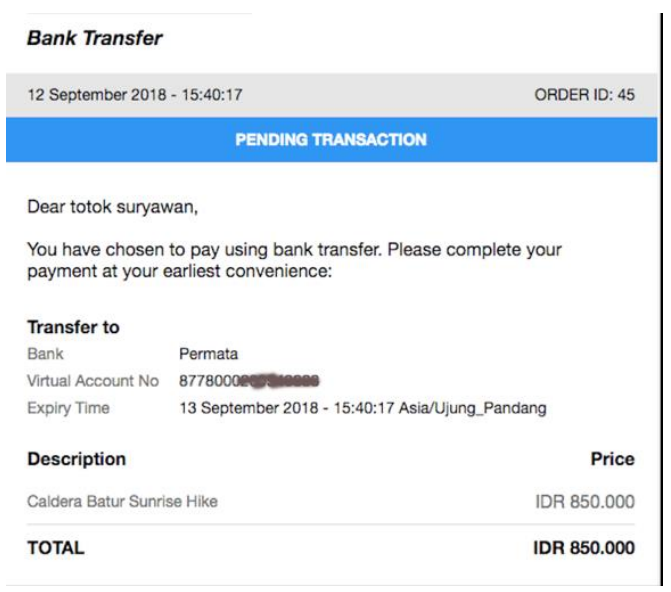

Gambar 18 Tagihan di Email Customer

\section{PENGUJIAN SISTEM}

Hasil dari sistem yang dikembangkan telah dilakukan pengujian dan secara fungsional semua fitur bisa berjalan dengan baik. Berikut Tabel 1 menunjukan hasil dari pengujian yang telah dilakukan.

Tabel 1: Hasil Pengujian

\begin{tabular}{|c|c|c|c|c|}
\hline No. & Fungsional & Skenario & Hasil & Ket \\
\hline 1 & $\begin{array}{l}\text { Pendaftaran } \\
\text { Client }\end{array}$ & $\begin{array}{l}\text { Client mengaskes halaman pendaftaran } \\
\text { dan melengkapi semua form pendaftaran }\end{array}$ & $\begin{array}{l}\text { Pendaftaran berhasil dan berada di } \\
\text { halaman profile client }\end{array}$ & sesuai \\
\hline 2 & $\begin{array}{l}\text { Lupa } \\
\text { Password }\end{array}$ & $\begin{array}{l}\text { Client memasukan email di form reset } \\
\text { password, sistem akan mengirimkan url } \\
\text { ke email pengguna yang berisi form } \\
\text { rubah password }\end{array}$ & $\begin{array}{l}\text { Halaman konfirmasi password } \\
\text { berhasil dirubah }\end{array}$ & sesuai \\
\hline 3 & Login Client & $\begin{array}{l}\text { Client memasukan username dan } \\
\text { password pada form login }\end{array}$ & $\begin{array}{l}\text { Login berhasil dan berada di } \\
\text { halaman dashboard client }\end{array}$ & sesuai \\
\hline 4 & $\begin{array}{l}\text { Login } \\
\text { Pengguna }\end{array}$ & $\begin{array}{l}\text { Pengguna memasukan username dan } \\
\text { password di halaman login pengguna }\end{array}$ & $\begin{array}{l}\text { Login berhasil dan berada di } \\
\text { halaman pengguna }\end{array}$ & sesuai \\
\hline 5 & $\begin{array}{l}\text { General } \\
\text { Seeting }\end{array}$ & $\begin{array}{l}\text { Client memasukan data perusahaan, } \\
\text { jenis mata uang, jenis pembayaran, serta } \\
\text { limit booking }\end{array}$ & $\begin{array}{l}\text { Pengaturan berhasil dilakukan dan } \\
\text { data perusahaan tersimpan di } \\
\text { sistem }\end{array}$ & sesuai \\
\hline 6 & $\begin{array}{l}\text { Integrasi } \\
\text { website } \\
\text { client }\end{array}$ & $\begin{array}{l}\text { Client menambahkan url dan nama } \\
\text { website sehingga, sistem menampilkan } \\
\text { API dan API tersebut bisa digunakan di } \\
\text { plagin yang telah diinstall di website } \\
\text { client }\end{array}$ & $\begin{array}{l}\text { Url website client berhasil } \\
\text { ditambahkan, instalasi, aktivasi, } \\
\text { dan konfigurasi API berhasil } \\
\text { dilakukan di website client }\end{array}$ & sesuai \\
\hline 7 & $\begin{array}{l}\text { Manajemen } \\
\text { kendaraan }\end{array}$ & $\begin{array}{l}\text { Client berada pada form tambah data } \\
\text { kendaraan dan menambahkan data } \\
\text { kendaraan serta status kendaraan }\end{array}$ & $\begin{array}{l}\text { Data kendaraan berhasil } \\
\text { ditambahkan dan sistem } \\
\text { menampilkan semua data } \\
\text { kendaraan yang ada di sistem }\end{array}$ & sesuai \\
\hline
\end{tabular}




\begin{tabular}{|c|c|c|c|c|}
\hline 8 & $\begin{array}{l}\text { Manajemen } \\
\text { pickup }\end{array}$ & $\begin{array}{l}\text { Client berada pada form tambah data } \\
\text { pickup dan menambahkan data pickup } \\
\text { serta status pickup }\end{array}$ & $\begin{array}{l}\text { Data pickup berhasil ditambahkan } \\
\text { dan sistem menampilkan semua } \\
\text { data pickup yang ada di sistem }\end{array}$ & sesuai \\
\hline 9 & $\begin{array}{l}\text { Manajemen } \\
\text { tour }\end{array}$ & $\begin{array}{l}\text { Client berada pada form tambah data } \\
\text { tour dan menambahkan data tour, detail } \\
\text { tour, beserta foto-foto }\end{array}$ & $\begin{array}{l}\text { Data tour berhasil ditambahkan } \\
\text { dan sistem menampilkan semua } \\
\text { data tour yang terlihat di sistem. } \\
\text { Data tour ini juga ditampilkan di } \\
\text { website client berupa tour list }\end{array}$ & sesuai \\
\hline 10 & $\begin{array}{l}\text { Booking } \\
\text { oleh } \\
\text { Customer }\end{array}$ & $\begin{array}{l}\text { Customer (wisatawan) berada pada } \\
\text { detail tour dan melengkapi form } \\
\text { booking, detail reservasi di website } \\
\text { client }\end{array}$ & $\begin{array}{l}\text { Data booking dan reservasi } \\
\text { tersimpan dan sistem akan } \\
\text { menampilkan metode pembayaran } \\
\text { untuk customer }\end{array}$ & sesuai \\
\hline 11 & $\begin{array}{l}\text { Pembayaran } \\
\text { oleh } \\
\text { Customer }\end{array}$ & $\begin{array}{l}\text { Customer berada pada halaman } \\
\text { pembayaran dari payment gateway dan } \\
\text { menekan tombol book, payment } \\
\text { gateway akan menampilkan virtual } \\
\text { account, dan mengirimkan tagihan ke } \\
\text { email customer }\end{array}$ & $\begin{array}{l}\text { Virtual account berhasil } \\
\text { ditampilkan dan customer } \\
\text { mendapatkan tagihan di email }\end{array}$ & sesuai \\
\hline 12 & $\begin{array}{l}\text { Manajemen } \\
\text { booking }\end{array}$ & $\begin{array}{l}\text { Client berada pada menu book, sistem } \\
\text { akan menampilkan semua booking dari } \\
\text { customer, dan client bisa merubah status } \\
\text { booking }\end{array}$ & $\begin{array}{l}\text { Status booking dari tamu bisa } \\
\text { berubah, dan sistem akan } \\
\text { menampilkan semua booking dari } \\
\text { tamu dengan status yang baru }\end{array}$ & sesuai \\
\hline
\end{tabular}

\section{SIMPULAN}

Dalam pada penelitian ini telah berhasil dikembangan sebuah sistem Cloud Reservation dan Payment System untuk Tour \& Activities yang mampu melakukan manajemen Tour \& Activities serta terintegrasi dengan payment geteway sehingga sistem bisa menampilkan fasilitas pembayaran, virtual account, cara pembayaran, serta mengirimkan tagihan ke email customer. Hasil penelitian menunjukan bahwa Scrum model dapat menghasilkan sebuah software berbasis cloud dengan resiko kegagalan bisa terlihat lebih cepat pada setiap backlog yang dikembangkan sehngga bisa mengurangi terjadinya software crisis.

\section{DAFTAR PUSTAKA}

[1] Oloyede, Alaya S M, and K. Adewole, "Development of an Online Bus Ticket Reservation System for a Transportation Service in Nigeria," Issn, vol. 5, no. 12, pp. 2222-1719, 2014.

[2] I. G. K. I. Pd, M. Somantri, and K. I. Satoto, "Perancangan Sistem Informasi Reservasi Hotel Graha Dewata Juwana Menggunakan Layanan Web Service," vol. 14, no. 1, pp. 38-41, 2012.

[3] O. Abdullah, M. Al-Maktari, R. Jamaludin, and A.-S. Hosam, "The Acceptance of Online Booking System (OBS) Based on the Theory of Reasoned Action (TRA): A Case of Sana'a University," Int. J. Sci. Eng. Res., vol. 3, no. 2, pp. 3-6, 2012.

[4] D. E. Sondakh, S. R. Pungus, P. Runtukahu, and R. Saroinsong, "Implementasi Teknologi Web Services Pada Aplikasi Pencarian Taksi," Cogito Smart J., vol. 2, no. 1, pp. 1-13, 2016.

[5] Erikson Damanik, "Perancangan Sistem Informasi Pembayaran Online Menggunakan Payment Gateway," JSM STMIK Mikroskil, vol. 13, no. 1, pp. 63-71, 2012.

[6] Y. Gamaliel and S. Suakanto, "Perancangan dan Implementasi Payment Gateway dengan metode 
Concurrency untuk Transaksi Nontunai," J. Telemat., vol. 12, no. $1,2017$.

[7] A. Haji Hosseinloo and K. Turitsyn, "Fundamental limits to nonlinear energy harvesting," Phys. Rev. Appl., vol. 4, no. 6, pp. 41-50, 2015.

[8] P. Adi, "Scrum Method Implementation in a Software Development Project Management," Int. J. Adv. Comput. Sci. Appl., vol. 6, no. 9, pp. 198-204, 2015.

[9] K. N. Rao, G. K. Naidu, and P. Chakka, "A study of the Agile software development methods, applicability and implications in industry," Int. J. Softw. Eng. its Appl., vol. 5, no. 2, pp. 35-46, 2011.

[10] C. Science, "Agile software development methodology," vol. 2, no. 1, pp. 22-27, 2015. 